\title{
Telemedicine in Malignant and Nonmalignant Hematology: Systematic Review of Pediatric and Adult Studies
}

\author{
Aashaka C Shah ${ }^{1}$, BS; Linda C O’Dwyer ${ }^{2}$, MA, MSLIS; Sherif M Badawy ${ }^{3,4}$, MBBCh, MS, MD \\ ${ }^{1}$ Department of Medical Education, University of Illinois College of Medicine, Chicago, IL, United States \\ ${ }^{2}$ Galter Health Sciences Library and Learning Center, Northwestern University Feinberg School of Medicine, Chicago, IL, United States \\ ${ }^{3}$ Division of Pediatric Hematology, Oncology, Neuro-Oncology \& Stem Cell Transplantation, Ann \& Robert H Lurie Children's Hospital of Chicago, \\ Chicago, IL, United States \\ ${ }^{4}$ Department of Pediatrics, Northwestern University Feinberg School of Medicine, Chicago, IL, United States
}

\section{Corresponding Author:}

Sherif M Badawy, MBBCh, MS, MD

Division of Pediatric Hematology, Oncology, Neuro-Oncology \& Stem Cell Transplantation

Ann \& Robert H Lurie Children's Hospital of Chicago

225 E Chicago Avenue, Box \#30

Chicago, IL, 60611

United States

Phone: 13122274000 ext 74836

Fax: 13122279373

Email: sbadawy@luriechildrens.org

\section{Abstract}

Background: Telemedicine, including video-, web-, and telephone-based interventions, is used in adult and pediatric populations to deliver health care and communicate with patients. In the realm of hematology, telemedicine has recently been used to safely and efficiently monitor treatment side-effects, perform consultations, and broaden the reach of subspecialty care.

Objective: We aimed to synthesize and analyze information regarding the feasibility, acceptability, and potential benefits of telemedicine interventions in malignant and nonmalignant hematology, as well as assess the recognized limitations of these interventions.

Methods: Studies were identified through a comprehensive Medical Subject Headings (MeSH) search on the PubMed MEDLINE, Controlled Register of Clinical Trials (Cochrane CENTRAL from Wiley), Embase, and CINAHL (EBSCO) databases on February 7, 2018. A second search, utilizing the same search strategy, was performed on October 1, 2020. We followed the Preferred Reporting Items for Systematic Reviews and Meta-Analyses (PRISMA) guidelines in the reporting of included evidence. Included studies were original articles researching the feasibility, acceptability, and clinical outcomes of telemedicine or telehealth interventions in pediatric or adult populations with malignant or nonmalignant hematological conditions. Data items in the extraction form included first author name, publication year, country, malignant or nonmalignant hematological condition or disease focus of the study, participant age, participant age subgroup (pediatric or adult), study design and setting, telemedicine intervention type and description, study purpose, and main study outcomes.

Results: A total of 32 articles met the preset criteria and were included in this study. Most (25/32) studies were conducted in adults, and the remaining (7/32) were conducted in the pediatric population. Of the 32 studies, 12 studied malignant hematological conditions, 18 studied nonmalignant conditions, and two studied both malignant and nonmalignant conditions. Study types included pilot study (11/32), retrospective study (9/32), randomized controlled trial (6/32), cross-sectional study (2/32), case study (1/32), pre-post study (1/32), noncomparative prospective study (1/32), and prospective cohort study (1/32). The three main types of telemedicine interventions utilized across all studies were video-based (9/32), telephone-based (9/32), and web-based interventions (14/32). Study results showed comparable outcomes between telemedicine and traditional patient encounter groups across both pediatric and adult populations for malignant and nonmalignant hematological conditions.

Conclusions: Evidence from this review suggests that telemedicine use in nonmalignant and malignant hematology provides similar or improved health care compared to face-to-face encounters in both pediatric and adult populations. Telemedicine interventions utilized in the included studies were well received in both pediatric and adult settings. However, more research is needed to determine the efficacy of implementing more widespread use of telemedicine for hematological conditions. 
(JMIR Mhealth Uhealth 2021;9(7):e29619) doi: 10.2196/29619

\section{KEYWORDS}

telemedicine; telehealth; eHealth; Digital Health; Digital Medicine; mHealth; hematology; malignant; nonmalignant; intervention

\section{Introduction}

Globally, we are facing a growing shortage of specialist physicians, coupled with inequity in patient access to quality care [1-3]. In America alone, only 30 specialists practice for every 100,000 people living in rural communities compared to 263 specialists in urban environments [4]. This shortage is further exacerbated when examined by subspecialty, making it progressively more difficult for patients to reach their physicians and obtain necessary treatments [4]. Thus, health care officials have turned to the field of telemedicine to leverage technological tools with the goal of expanding and optimizing the delivery of medical care [3].

Telemedicine is defined as the use of teleconferencing interventions to provide and deliver health care to patients [5]. Although telemedicine is classified under the broader term, "telehealth," ambiguity surrounding which forms of technology each category encompasses still exists, and both terms are often used interchangeably [6]. Telemedicine is a subset of telehealth, which is defined as the use of technology in any aspect of health care. Telemedicine is specifically utilized for clinical patient care, not exclusively for research purposes.

Telemedicine has grown in parallel with society's growing desire for convenience, efficiency, and productivity, and today, frequently used modes of telemedicine include videoconferencing, email, wearable devices, cellular phones, and various mobile apps [3,6]. These new systems of telemedicine are promising for mitigating the current challenges in health care reform, since they offer medical professionals the novel opportunity to extend their presence to settings outside of their immediate reach [3]. In doing so, telemedicine presents health care industries with the potential to provide more cost-effective treatments, support patient self-management, respond to the growing demand for specialists, and uncover avenues for advancing the practice of medicine in underserved areas worldwide [3,6-9]. Furthermore, access to personal and mobile technologies is ubiquitous [10-14], which has provided an opportunity to optimize digital health care delivery approaches, including telemedicine. However, despite these benefits, there remain obstacles to implementing telemedicine in daily practice $[15,16]$. Barriers, including stable internet access, cost, and patient desire for in-person appointments, must be addressed for telemedicine to reach its full potential $[15,16]$. Nevertheless, there has been growing evidence to support the utility and clinical applications of various digital approaches for health care delivery, including telemedicine, across pediatric and adult populations with or without chronic medical conditions [17-39], although the cost-effectiveness remains unclear [40,41].

In the field of hematology, recent advances in telemedicine have been used to conduct patient visits, monitor treatment side-effects, and perform consultations [42-45]. During the current COVID-19 pandemic, telemedicine use in outpatient settings, such as hematology clinics, has increased significantly owing to stay-at-home orders and efforts to lessen exposure to ill patients [46,47]. Videoconferencing interventions have proved to be a safe and efficient way for health care providers and patients to continue managing and monitoring chronic health conditions, especially for sickle cell disease and other hematological conditions [48]. Additionally, both adult and pediatric populations in underserved areas have benefitted from telemedicine's ability to connect them to specialists in different cities [48].

In this systematic review, we evaluated the evidence available in the literature to analyze the feasibility, acceptability, and potential benefits of telemedicine interventions in malignant and nonmalignant hematology and assess the current limitations of utilizing these interventions. Owing to the heterogeneity of the included studies, the methods by which feasibility, accessibility, and clinical outcomes were assessed vary among the studies. In this review, we use these terms broadly to encompass the different interpretations of these objectives. We more specifically define each study's main objectives in the Results section.

\section{Methods}

\section{Guideline}

We followed the Preferred Reporting Items for Systematic Reviews and Meta-Analyses (PRISMA) guidelines for reporting of evidence across the studies we reviewed [49].

\section{Article Retrieval}

A librarian, in collaboration with other review authors, collaboratively developed the highly sensitive Medical Subject Headings (MeSH) term-based search strategies and ran searches in the following databases: PubMed MEDLINE, Controlled Register of Clinical Trials (Cochrane CENTRAL from Wiley), Embase, and CINAHL (EBSCO), on February 7, 2018 (Multimedia Appendix 1). The bibliographies of hand-searched articles that had been previously identified were also included. The search strategy focused on articles that studied telemedicine and telehealth interventions for malignant and nonmalignant hematological conditions in both pediatric and adult populations. No date limits were applied to the search. On October 1, 2020, another literature search was conducted on PubMed to identify articles that were published since the last literature search and that met the inclusion criteria. The second literature search utilized the same search strategy as the first search.

\section{Study Selection}

The inclusion criteria were as follows: (1) studies involving pediatric or adult populations with malignant or nonmalignant hematological conditions, (2) studies involving telemedicine or telehealth interventions, (3) studies that included feasibility, acceptability, and clinical outcomes of the interventions as the primary or secondary outcomes, (4) original research articles, 
and (5) studies designed as a randomized controlled trial (RCT), cohort study, pilot study, retrospective study, or cross-sectional study. "Telemedicine" and "telehealth" are often used interchangeably, so both terms were relevant to the search despite having different semantic meanings. The exclusion criteria were as follows: (1) studies not related to hematology, (2) studies without a telemedicine intervention, (3) nonclinical research studies, (4) abstracts only or nonoriginal research papers, and (5) studies not in English.

\section{Data Extraction}

A standardized format was used for data extraction. Data items in the extraction form included first author name, publication year, country, malignant or nonmalignant hematological condition or disease focus of the study, participant age, participant age subgroup (adult or pediatric), study design and setting, telemedicine intervention type and description (telephone, remote management, videoconferencing, etc), study purpose, and main outcomes. Two authors coded all included articles individually. Disagreements were resolved by discussion.

\section{Quality Assessment and Evidence Strength}

Studies described in each article were evaluated for the quality of evidence using the GRADE (Grades of Recommendation, Assessment, Development, and Evaluation) approach [50]. This method evaluates four key domains, including consistency, directness, risk for bias, and precision of the evidence. Two authors graded all included articles individually. Disagreements were similarly resolved by discussion, if needed.

\section{Results}

\section{Literature Search}

Our literature search identified 1047 records. After removing duplicates, 878 articles remained. Two authors independently screened the titles and abstracts of 878 records, and 774 were excluded. Two authors independently screened the remaining 104 full-text articles, and 32 met our inclusion criteria for eligibility. The study flowchart and reasons for exclusion of full-text papers were documented in an adapted PRISMA study flowchart (Figure 1). We did not identify any non-English articles that met our inclusion criteria.

Figure 1. PRISMA (Preferred Reporting Items for Systematic Reviews and Meta-Analyses) flow diagram for the included studies.

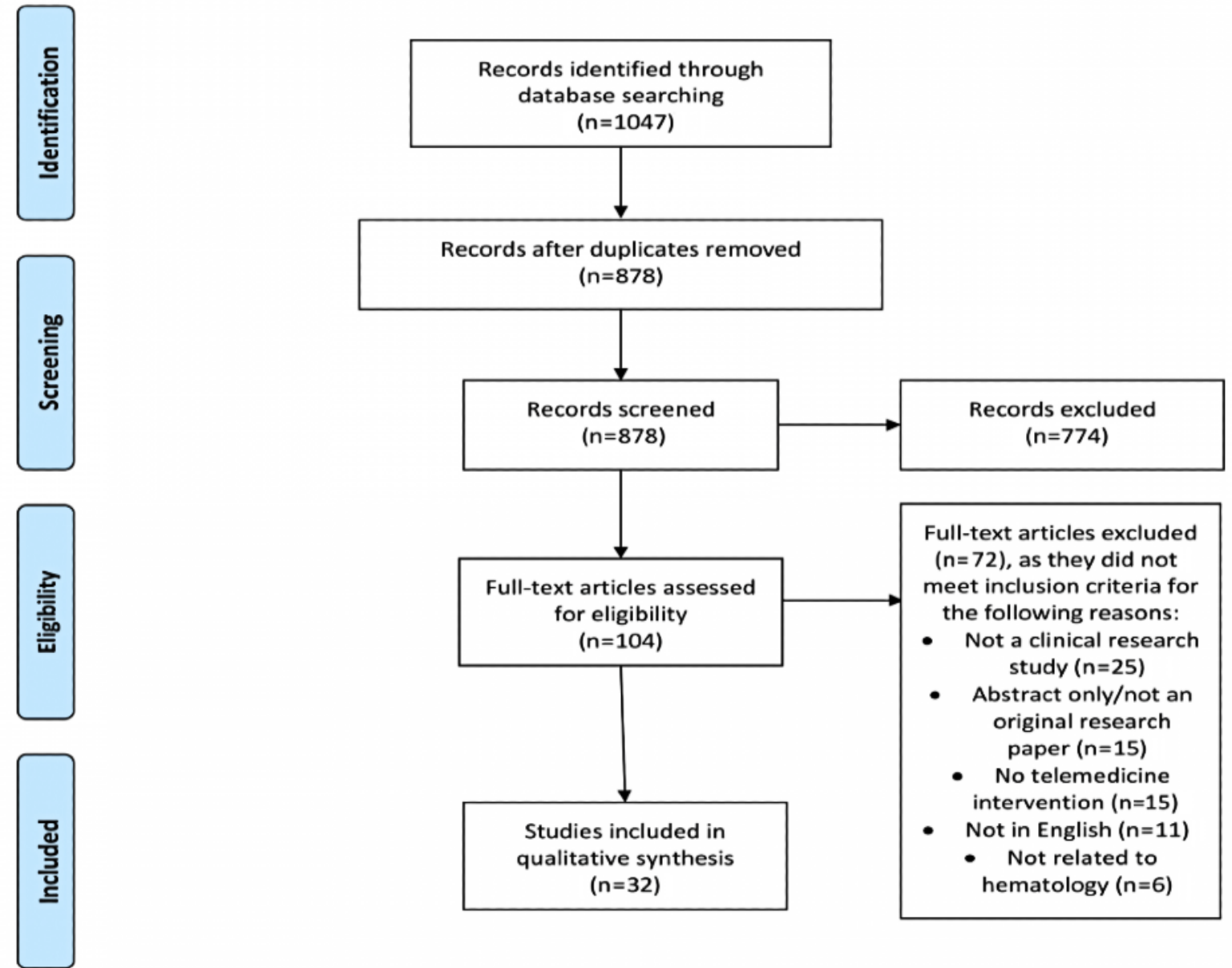

A total of 32 articles were included in this systematic review. Most $(25 / 32,78 \%)$ studies were conducted with adults [42,51-74], while the remaining $(7 / 32,22 \%)$ were conducted in the pediatric population [75-81]. The studies addressed whether a telemedical intervention for patients with malignant and/or nonmalignant hematological conditions is a safe, feasible, and efficacious method of health care provision.

\section{Description of the Included Studies}

Table 1 and Table 2 summarize study characteristics for the pediatric and adult populations, respectively. Out of the 32 
studies, $16(50 \%)$ were conducted in the United States [52,53,55-57,60,62,63,65,69,71-73,77,78,81], $6(19 \%)$ in Canada [58,64,68,74,75,79], 2 (6\%) each in Australia [42,61], India $[51,76]$, and Italy [54,70], and $1(3 \%)$ each in Brazil [80], France [59], Germany [66], Ireland [67], and Rwanda [81]. Although the search retrieval included results published since 1980, the earliest eligible study was from 1998, which corresponds to our knowledge of when telemedicine was first introduced [71]. The most recent study was published in 2018 [56].
The sample size ranged from 1 [74] to 217,014 [62], with a median of 157 and a mean of 7977 participants per study. Overall, 21 studies enrolled $\geq 100$ participants $[51,53-60,62,63,65-70,72,73,76,80]$ and 11 had $<100$ participants [42,52,61,64,71,74,75,77-79,81].

Of the 32 included studies, $12(34 \%)$ studied malignant hematological conditions [42,53,58-61,64,67,69,77,80,81], 18 $(59 \%)$ studied nonmalignant conditions with percentages [51,52,54-57,62,63,65,66,68,70-74,76,78], and $2(6 \%)$ studied both malignant and nonmalignant conditions [75,79].

Table 1. Characteristics of pediatric malignant and nonmalignant hematology studies.

\begin{tabular}{|c|c|c|c|c|c|}
\hline Source (country) & Condition & $\begin{array}{l}\text { Sample size and } \\
\text { age }\end{array}$ & Study design & Study setting & Grade \\
\hline $\begin{array}{l}\text { Adler } 2015[75] \\
\text { (Canada) }\end{array}$ & $\begin{array}{l}\text { Leukemia, lymphoma, solid tu- } \\
\text { mor, neuro-oncology, and nonma- } \\
\text { lignant hematology }\end{array}$ & $\begin{array}{l}\mathrm{N}=54 \text {; age: } 0-18 \\
\text { years }\end{array}$ & Pilot study & $\begin{array}{l}\text { The Hospital for Sick Kids (Toronto, } \\
\text { Canada) and six telemedicine facilities } \\
\text { in Caribbean countries }\end{array}$ & Very low \\
\hline $\begin{array}{l}\text { Agarwal } 2014 \text { [76] } \\
\text { (India) }\end{array}$ & Thalassemia & $\mathrm{N}=112$ & Pilot study & $\begin{array}{l}\text { Participating centers in Italy, Pakistan, } \\
\text { and India }\end{array}$ & Very low \\
\hline $\begin{array}{l}\text { Cox } 2015 \text { [77] } \\
\text { (United States) }\end{array}$ & $\begin{array}{l}\text { Survivors of childhood brain tu- } \\
\text { mors or acute lymphoblastic } \\
\text { leukemia }\end{array}$ & $\begin{array}{l}\mathrm{N}=68 \text {; age: } 8-16 \\
\text { years }\end{array}$ & $\begin{array}{l}\text { Randomized con- } \\
\text { trolled trial }\end{array}$ & St. Jude Children's Research Hospital & Moderate \\
\hline $\begin{array}{l}\text { Jacobson } 2016[78] \\
\text { (United States) }\end{array}$ & Severe hemophilia & $\begin{array}{l}\mathrm{N}=12 \text {; age: } 10-18 \\
\text { years, mean age: } \\
10.25 \text { years }\end{array}$ & Pilot study & Hemophilia Treatment Center & Very low \\
\hline $\begin{array}{l}\text { Johnston } 2017 \text { [79] } \\
\text { (Canada) }\end{array}$ & $\begin{array}{l}\text { Any hematology and oncology } \\
\text { condition (majority anemia, } \\
\text { hemoglobinopathy, and bleeding } \\
\text { disorder) }\end{array}$ & $\mathrm{N}=85$ & $\begin{array}{l}\text { Cross-sectional } \\
\text { study }\end{array}$ & $\begin{array}{l}\text { Champlain BASE e-Consult service } \\
\text { (Ottawa, Canada) through a web portal }\end{array}$ & Low \\
\hline $\begin{array}{l}\text { Pedrosa } 2017[80] \\
\text { (Brazil) }\end{array}$ & Acute lymphoblastic leukemia & $\begin{array}{l}\mathrm{N}=163 \text {; age: } 1-15 \\
\text { years }\end{array}$ & Pilot study & $\begin{array}{l}\text { Instituto Materno Infantil de Pernambu- } \\
\text { co (Recife, Brazil) and St. Jude Chil- } \\
\text { dren's Research Hospital }\end{array}$ & Very low \\
\hline $\begin{array}{l}\text { Stulac } 2016[81] \\
\text { (United States, } \\
\text { Rwanda) }\end{array}$ & $\begin{array}{l}\text { Lymphoma, sarcoma, leukemia, } \\
\text { and other malignancies }\end{array}$ & $\mathrm{N}=24$ & $\begin{array}{l}\text { Retrospective } \\
\text { study }\end{array}$ & $\begin{array}{l}\text { Rural district hospitals in Rwanda } \\
\text { (Rwinkwavu, Kirehe, and Butaro) }\end{array}$ & Very low \\
\hline
\end{tabular}


Table 2. Characteristics of adult malignant and nonmalignant hematology studies.

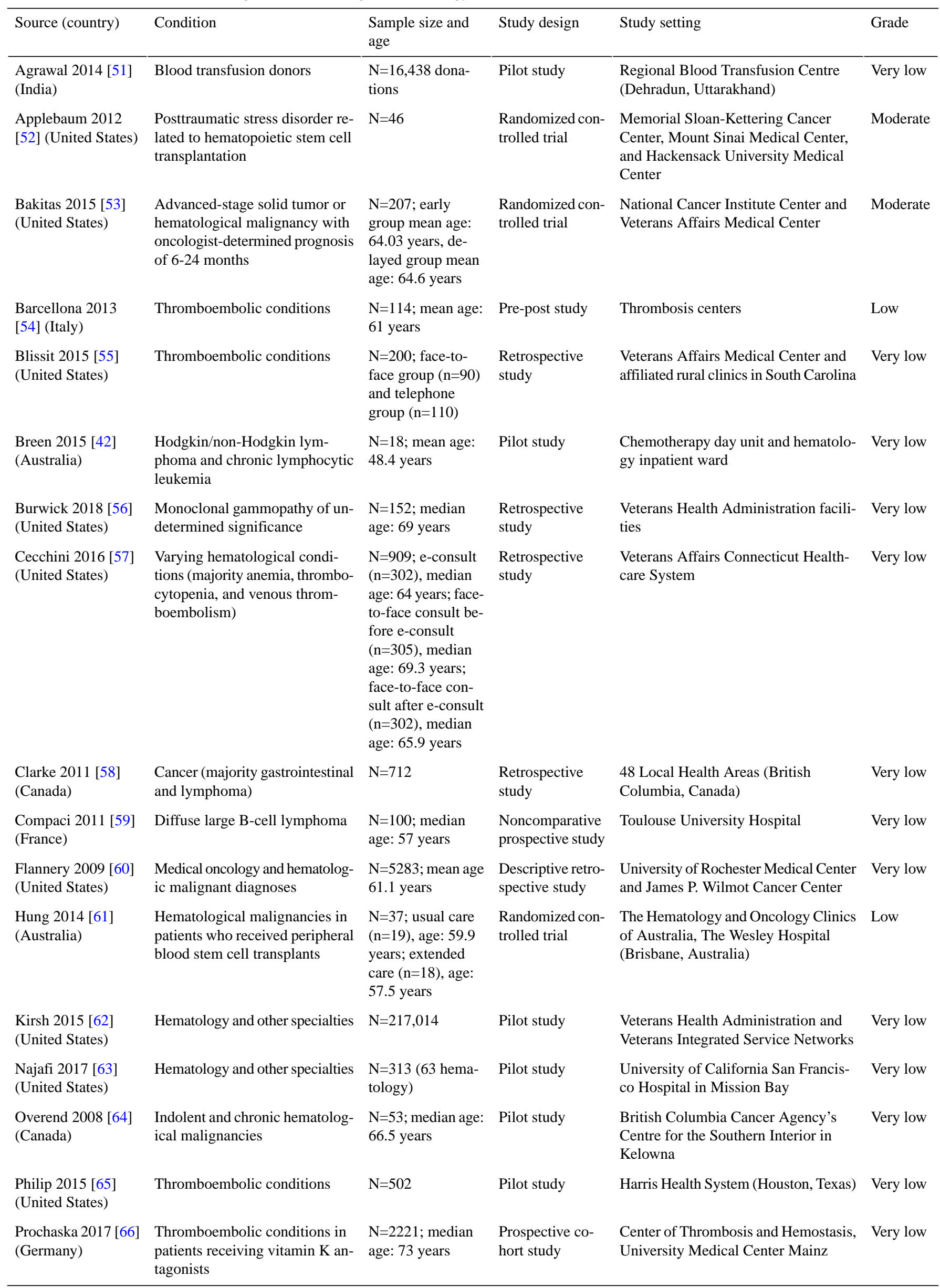




\begin{tabular}{|c|c|c|c|c|c|}
\hline Source (country) & Condition & $\begin{array}{l}\text { Sample size and } \\
\text { age }\end{array}$ & Study design & Study setting & Grade \\
\hline $\begin{array}{l}\text { Reid } 2011 \text { [67] (Ire- } \\
\text { land) }\end{array}$ & Cancer & $\mathrm{N}=7498$ & $\begin{array}{l}\text { Retrospective } \\
\text { study }\end{array}$ & Regional Cancer Centre & Very low \\
\hline $\begin{array}{l}\text { Skeith } 2017[68] \\
\text { (Canada) }\end{array}$ & Thromboembolic conditions & $\begin{array}{l}\mathrm{N}=162 ; \text { mean age: } \\
58.3 \text { years }\end{array}$ & $\begin{array}{l}\text { Cross-sectional } \\
\text { study }\end{array}$ & $\begin{array}{l}\text { Champlain Local Health Integration } \\
\text { Network (Ontario, Canada) }\end{array}$ & Very low \\
\hline $\begin{array}{l}\text { Testa } 2005[70] \\
\text { (Italy) }\end{array}$ & Thromboembolic conditions & $\mathrm{N}=1393$ & $\begin{array}{l}\text { Retrospective } \\
\text { study }\end{array}$ & $\begin{array}{l}11 \text { peripheral health care units and } \\
\text { homes of } 20 \text { self-testing patients }\end{array}$ & Low \\
\hline $\begin{array}{l}\text { Woods } 2000[72] \\
\text { (United States) }\end{array}$ & Sickle cell disease & $\begin{array}{l}N=466 ; \text { mean age: } \\
27 \text { years }\end{array}$ & $\begin{array}{l}\text { Retrospective } \\
\text { study }\end{array}$ & $\begin{array}{l}\text { Telemedicine clinical sites of The } \\
\text { Medical College of Georgia Sickle Cell } \\
\text { Center (Augusta, Georgia) }\end{array}$ & Very low \\
\hline $\begin{array}{l}\text { Woods } 1999[73] \\
\text { (United States) }\end{array}$ & Sickle cell disease & $\begin{array}{l}\mathrm{N}=120 ; \text { standard } \\
(\mathrm{n}=60) \text {, age: } 33.32 \\
\text { years; telemedicine } \\
(\mathrm{n}=60) \text {, age: } 29.37 \\
\text { years }\end{array}$ & $\begin{array}{l}\text { Randomized con- } \\
\text { trolled trial }\end{array}$ & $\begin{array}{l}\text { Telemedicine clinical sites of The } \\
\text { Medical College of Georgia Sickle Cell } \\
\text { Center (Augusta, Georgia) }\end{array}$ & Very low \\
\hline $\begin{array}{l}\text { Woods } 1998[71] \\
\text { (United States) }\end{array}$ & Sickle cell disease & $\begin{array}{l}\mathrm{N}=28 ; \text { mean age: } \\
29.1 \text { years }\end{array}$ & Pilot study & $\begin{array}{l}\text { Remote telemedicine clinic site in Ma- } \\
\text { con (affiliated with Medical Center of } \\
\text { Central Georgia) }\end{array}$ & Very low \\
\hline $\begin{array}{l}\text { Wright } 2007[74] \\
\text { (Canada) }\end{array}$ & $\begin{array}{l}\text { Allogenic blood and hemopoietic } \\
\text { stem cell transplantation }\end{array}$ & $\mathrm{N}=1$ & Case study & $\begin{array}{l}\text { Princess Margaret Hospital (Toronto, } \\
\text { Ontario) }\end{array}$ & Very low \\
\hline
\end{tabular}

\section{Methodological Quality of the Studies}

Of the 32 studies, $11(34 \%)$ were pilot studies [42,51,62-65,71,75,76,78,80], $9(28 \%)$ were retrospective studies $[55-58,60,67,70,72,81], 6 \quad 6 \%)$ were RCTs [52,53,61,69,73,77], $2(6 \%)$ were cross-sectional studies [68,79], 1 (3\%) was a case study [74], 1 (3\%) was a pre-post study [54], $1(3 \%)$ was a noncomparative prospective study [59], and 1 (3\%) was a prospective cohort study [66]. Of the 6 RCTs, 1 $(17 \%)$ was a single-blinded study and the remaining $5(83 \%)$ had no blinding. Follow-up activity after the telemedicine interventions was tracked in six of the studies in the forms of postintervention neuroimaging examination $(n=1,17 \%)$ [77], follow-up assessments $(\mathrm{n}=3,50 \%)[52,53,64]$, number of patient visits $(n=1,17 \%)$ [62], and interview $(n=1,17 \%)$ [82]. Based on the GRADE criteria, four included studies were rated as "moderate" [52,53,69,77], four were rated as "low" $[54,61,70,79]$, and 24 were rated as "very low" [42,51,55-60,62-68,71-76,78,80,81]. The "low" and "very low" ratings were mainly a result of the type of study and indirectness of evidence.

\section{Description of Telemedicine Approaches}

Table 3 and Table 4 provide detailed descriptions of the study purpose, telemedicine intervention used, and main findings of the included pediatric and adult studies, respectively. Additional study outcomes for pediatric and adult studies are also reported in Multimedia Appendix 2 and Multimedia Appendix 3, respectively. There were the following three main categories of telemedicine interventions in the included studies: video $(\mathrm{n}=9) \quad[53,58,64,71-75,78], \quad$ telephone $\quad(\mathrm{n}=9)$ $[52,55,59-61,65,67,76,81], \quad$ and web $\quad(n=14)$ $[42,51,54,56,57,62,63,66,68-70,77,79,80]$. Video interventions used cameras and videoconferences to visually connect the patients to the providers. Telephone interventions involved nurse triages, counseling sessions over the phone, and telephone help lines available to patients $24 / 7$. Web-based telemedicine interventions included online interfaces for patients to send and store data and to monitor their conditions from home while still maintaining intermittent contact with practitioners. 
Table 3. Summary of the interventions and outcomes of the included studies in pediatric populations.

\begin{tabular}{|c|c|c|c|}
\hline Source (country) & Purpose & Telemedicine intervention & Main findings \\
\hline \multirow[t]{2}{*}{$\begin{array}{l}\text { Adler } 2015 \text { [75] } \\
\text { (Canada) }\end{array}$} & \multirow[t]{2}{*}{$\begin{array}{l}\text { Improve outcomes and quality of life for } \\
\text { children with cancer and blood disorders } \\
\text { in the Caribbean by using telemedicine }\end{array}$} & \multirow[t]{2}{*}{$\begin{array}{l}\text { Utilizing telemedicine facilities to conduct } \\
\text { patient case consultations and discussions } \\
\text { in real time }\end{array}$} & $\begin{array}{l}\text { Satisfaction: } \\
\text { Adequate to excellent overall attendee } \\
\text { satisfaction rates }\end{array}$ \\
\hline & & & Good to excellent patient care education \\
\hline
\end{tabular}

Agarwal $2014 \quad$ Leverage an online collaborative informa[76] (India) tion technology platform to improve outcomes of children with thalassemia receiving bone marrow transplants

Cox 2015 [77] Evaluate the feasibility and acceptability (United States) of a remote automated intervention to address late cognitive effects among childhood cancer survivors

Jacobson 2016

[78] (United

States)

Johnston 2017

[79] (Canada)

Evaluate the feasibility of using videoconferencing to assess breakthrough bleeds in children with severe hemophilia
Online open-access database with data

storage, telemedicine, and knowledge exchange capabilities

Automated rotating exercises to train visual-spatial and verbal working memory over a 5- to 9-week period satisfaction rates

Clinical outcomes: Comparable health outcomes with decreased cost

Increased rates of family screening Targeted prenatal diagnoses for pregnant women

Feasibility:

Strong compliance with the intervention $(88 \%)$ and pre- and postintervention imaging (91\% and 93\%, respectively)

Satisfaction:

Caregivers viewed the program as beneficial $(70 \%)$ and would recommend it to others $(93 \%)$

Videoconferencing was utilized by health Satisfaction: care providers to assess the patient's condition during breakthrough bleeding

Comparable or improved satisfaction was reported among health care providers and caregivers with videoconferencing versus phone call

Analyze the use of e-consult by primary Web portal based e-consult service for care providers for pediatric oncology and pediatric oncology and hematology hematology conditions

Satisfaction:

High satisfaction ratings of e-consult services from primary care providers and pediatric hematology/oncology specialists Feasibility:

$40 \%$ deferral of consults that were originally supposed to be in person

Pedrosa 2017

[80] (Brazil)

Evaluate the efficacy of a telemedicinebased knowledge-sharing program to improve management of childhood acute lymphoblastic leukemia

Stulac 2016 [81] Evaluate the impact of partnership-based (United treatment of pediatric cancer patients in

States/Rwanda) Rwanda by physicians and nurses based in Rwanda and United States
Teleconferencing-based knowledge-sharing program between hospitals in the United States and Brazil

Collaboration between clinicians based in Rwanda and United States via telephone, email, and online databases to manage pediatric cancer cases
Clinical outcomes:

Decreases in overall mortality $(31.0 \%$ to $12.8 \%)$, early death $(8.1 \%$ to $3.6 \%)$, and relapse $(10.2 \%$ to $7.9 \%)$ after institution of the telemedicine program

Clinical outcomes:

Mean overall survival of 31 months

Mean disease-free survival of 18 months 
Table 4. Summary of the interventions and outcomes of the included studies in adult populations.

\begin{tabular}{llll}
\hline Source (Country) & Purpose & Telemedicine intervention & Main findings \\
\hline $\begin{array}{l}\text { Agrawal 2014 } \\
\text { [51] (India) }\end{array}$ & $\begin{array}{l}\text { Improve blood donor recruitment, reten- } \\
\text { tion, and relationship management }\end{array}$ & $\begin{array}{l}\text { Call center staffed with personnel to con- } \\
\text { duct phone calls and send SMS text mes- } \\
\text { sages to recruit and build relationships } \\
\text { with blood donors }\end{array}$ & $\begin{array}{l}\text { Telerecruitment contributed to 63\% of in- } \\
\text { house and 13\% of total donations } \\
\text { Clinical outcomes: } \\
\text { Telerecruitment helped establish relation- } \\
\text { ships with blood donors and the society }\end{array}$ \\
& & in general &
\end{tabular}

Applebaum 2012 Determine the relationship between thera- Telephone-administered cognitive behav[52] (United States) peutic alliance through telephone delivered ioral therapy cognitive behavioral therapy and psychotherapy outcomes in survivors of hemopoietic stem cell transplantation with posttraumatic stress disorder

Bakitas 2015 [53] Investigate the effect of early versus de(United States) layed palliative care on the quality of life of advanced-stage cancer patients

Barcellona 2013 Compare the effect of a point-of-care [54] (Italy) home monitoring testing device supplemented by telemedicine with conventional monitoring in patients chronically treated with anti-vitamin $\mathrm{K}$ antagonists

Blissit 2015 [55] Compare the effect of telephone versus (United States) face-to-face care on time spent within the therapeutic range for patients on warfarin

Breen 2015 [42] Evaluate a real-time remote telemedicine (Australia) system to improve monitoring and management of side-effects in patients with blood cancers

Burwick 2018

[56] (United

States)
Identify ways to improve care of patients with monoclonal gammopathy of undetermined significance through e-consult use
TAONet telemedicine platform allowed patients to send international normalized ratio (INR) results and other clinical information to the Thrombosis Centre, as well as communicate with providers, adjust

Pharmacist-managed care via telephone for patients taking warfarin

Smart phone app collected ambulatory patient health data in real time and transmitted this information to the treatment hospital where alerts were generated for actioning based on imputed patient data

Review of electronic hematology consults for monoclonal gammopathy of undetermined significance through e-consult use medications, and screen for serious events

\section{Clinical outcomes:}

Therapeutic alliance by telephone cognitive behavior therapy predicted decreased depressive symptoms, decreased general distress, and lower likelihood for re-experiencing symptoms

\section{Clinical outcomes:}

No statistically significant evidence to support improved patient-reported outcomes in early versus late palliative care groups

Statistically significant improved 1-year survival rate in early versus late palliative care groups $(P=.04)$

Clinical outcomes:

Greater blood checks and fewer missed INR checks in the home monitoring group Significant increase in time spent within the therapeutic range in the unstable group with home monitoring compared to conventional monitoring

No significant difference in time spent within the therapeutic range in the stable group with home monitoring compared to conventional monitoring

\section{Clinical outcomes:}

No significant difference in time spent within the therapeutic range, significant bleeding rates, death rates, and thromboembolic events between face-to-face and telephone groups

\section{Satisfaction:}

Patients reported increased feelings of empowerment and health awareness and adherence with the use of the application Clinical outcomes:

Patients were better able to recall side-effects when using the application.

Accessibility:

Short time (2 days) to completion of econsult

Majority of e-consults were low risk 


\begin{tabular}{lll}
\hline Source (Country) & Purpose & Telemedicine intervention \\
\hline $\begin{array}{l}\text { Cecchini 2016 } \\
\text { [57] (United }\end{array}$ & $\begin{array}{l}\text { Evaluate the efficacy of e-consults for the } \\
\text { management of hematological disorders }\end{array}$ & Electronic consults with hematologists \\
& &
\end{tabular}

Main findings

Satisfaction:

$65 \%$ of patients who responded said they preferred e-consults over face-to-face visits

All providers who responded said they were either "satisfied" or "very satisfied" with e-consults

Feasibility:

$18 \%$ drop in face-to-face consults within 2 years of e-consult implementation

Clarke 2011 [58] Assess oncology telehealth usage in (Canada) British Columbia

Compaci 2011

[59] (France)

Flannery 2009

[60] (United

States)

Define telephone call volume, distribution, and reason in an ambulatory oncology practice bulatory Medical Assistance phone calls in monitoring aggressive B-cell lymphoma treated with R-CHOP therapy
Oncology and genetic counselling appointments conducted with tele-conferencing units

Standardized 10-minute telephone call twice a week by an oncology nurse to monitor vitals and side-effects during chemotherapy treatment

Telephone triage line managed by nurses to address patient symptoms

Hung 2014 [61] Evaluate the impact of telephone counsel(Australia) ing on nutrition and exercise after peripheral blood stem cell transplantation
Kirsh 2015 [62] Analyze the impact of e-consults in im(United States) proving specialty care access for veterans
Telephone counseling sessions conducted by a dietitian or exercise physiologist every 2 weeks for up to 100 days after transplantation
Feasibility:

Medical oncology teleconferences occurred more often than genetic counseling and medical genetics

Clinical outcomes:

A single medical oncologist conducted $58.7 \%$ of all telehealth encounters in 2009

Most common telehealth appointment types were gastrointestinal cancer and lymphoma

Clinical outcomes:

Lower incidences of secondary hospitalization, delayed treatment, and reduced relative dose intensity, toxic death, and red blood cell transfusion compared to literature

Feasibility:

Seven calls were made or received for every 10 scheduled appointments

Most calls were made on Monday mornings

$30 \%$ of calls were made for more than one reason

Clinical outcomes:

Increased, but not statistically significant, protein intake $(P=.17)$, cognitive functioning $(P=.34)$, and social functioning $(P=.17)$ in the extended care group versus usual care group

Decreased, but not statistically significant, weight loss $(P=.06)$ in the extended care group versus usual care group

E-consult service for various specialties

Feasibility:

Hematology had the second highest (after cardiology) rate of e-consults

Clinical outcomes:

Within the first 3 months after an e-consult, there was a decreased likelihood of a subsequent face-to-face visit $(P<.001)$

Within the first 3 months after an e-consult, there was an increased likelihood of a primary care visit $(P<.001)$ 


\begin{tabular}{ll}
\hline Source (Country) & Purpose \\
\hline $\begin{array}{l}\text { Najafi 2017 [63] } \\
\text { (United States) }\end{array}$ & $\begin{array}{l}\text { Evaluate the feasibility and acceptability } \\
\text { (by providers) of an inpatient e-consult } \\
\text { service }\end{array}$ \\
& \\
& \\
Determine the efficacy, safety, and patient \\
satisfaction of a nurse-led teleclinic to \\
manage patients with indolent and chronic \\
hematological malignancies
\end{tabular}

Nurse-led teleclinic interviews for hematology/oncology patients in between oncologist visits

Philip 2015 [65] (United States)
Telemedicine intervention

E-consult service for subspecialist consults

the

Prochaska 2017 Compare the outcomes of oral anticoagu[66] (Germany) lation patients managed by an eHealthbased coagulation service versus regular medical care

Reid 2011 [67] Investigate the usage and patient/caller (Ireland)
Evaluate the efficacy of a telephone-based pharmacist anticoagulation service
Telephone-based anticoagulation service run by pharmacists
Telephone service run by nurses experiaddress patient questions and concerns enced in oncology and chemotherapy to profile of a nurse-led chemotherapy telephone helpline
Electronic file was used to manage medication and data at remote locations and interface between patients and providers
Main findings

Feasibility:

Majority of hospitalists and consultants believe that e-consults are easy to use and efficient

Hematology had the second highest volume of e-consults

Satisfaction:

All hospitalists who completed the survey were satisfied with quality

$43 \%$ of consultants who completed the survey felt they were able to provide highquality care

Satisfaction:

$82 \%$ of patients felt strongly that they could talk easily and openly, and that the provider was able to understand their situation to provide satisfactory care

$62 \%$ reported they would participate in a teleclinic again

Accessibility:

Majority of patients did not feel that they needed to see a physician in person

Clinical outcomes:

Increase in clinical pharmacy patient volume at ambulatory care clinics after the intervention

No significant difference in time in the therapeutic range, hospitalization from thrombotic events or bleeding, work hours, and project completion rates between groups

\section{Clinical outcomes:}

eHealth service participants had lower rates of bleeding, hospitalization, and allcause mortality compared to participants who received regular medical care

\section{Feasibility:}

7498 calls received by helpline service

$35.2 \%$ of patients called with multiple symptoms or concerns

Accessibility:

$47.5 \%$ of face-to-face consultations were avoided

$4.3 \%$ of e-consults resulted in a follow-up referral that was not already scheduled

Clinical outcomes:

$36.8 \%$ of calls led to direct medical assessment

Skeith 2017 [68] Analyze the use and impact of e-consults

E-consult service for thrombosis medicine

Feasibility:

Most common referral topics were thrombophilia testing, superficial venous thrombosis, and venous thromboembolism anticoagulation

Satisfaction:

Positive responses by primary care providers regarding the e-consult service 


\begin{tabular}{|c|c|}
\hline Source (Country) & Purpose \\
\hline $\begin{array}{l}\text { Syrjala } 2011 \text { [69] } \\
\text { (United States) }\end{array}$ & $\begin{array}{l}\text { Describe the development and feasibility } \\
\text { of a new online survivorship care program } \\
\text { for cancer patients treated with hemopoi- } \\
\text { etic stem cell transplantation }\end{array}$ \\
\hline $\begin{array}{l}\text { Testa } 2005 \text { [70] } \\
\text { (Italy) }\end{array}$ & $\begin{array}{l}\text { Implement a telemedicine system to deliv- } \\
\text { er the same quality of care as traditional } \\
\text { medicine in anticoagulation management } \\
\text { especially for those living far away from } \\
\text { an anticoagulation center }\end{array}$ \\
\hline
\end{tabular}

Woods 2000 [72] Evaluate the efficacy of the Georgia (United States) statewide telemedicine program in improving access to health services for patients with sick cell disease in remote areas

Woods 1999 [73] Compare patient satisfaction between (United States) telemedicine encounters and standard care for the management of sickle cell disease in adults

Woods 1998 [71] Evaluate the efficacy of a telemedicine (United States) clinic for adult sickle cell patients

Telemedicine intervention
Survivorship care delivered remotely
through an online platform

Remote anticoagulation management via an electronic medical record system through which patients or health centers can send INR data to an anticoagulation clinic

Telemedicine clinic for sickle cell patients with assistance of nurses at remote locations

Telemedicine clinic for sickle cell patients with assistance of nurses at remote locations

tions

Telemedicine clinic for sickle cell patients with assistance of nurses at remote locations

E-clinic visits at local health centers using videoconferencing technology
Main findings

Feasibility:

$57 \%$ of participants required staff contact at least one time, usually for minor technical issues, or help in enrollment or the baseline assessment

Most contacts were initiated by email instead of telephone

Clinical outcomes:

No difference in time in the therapeutic range between anticoagulation clinics $(73 \%)$ and telemedicine use in general practitioner units $(73.4 \%)$

Telemedicine use in nursing homes showed a lower percentage in the therapeutic range $(66 \%)$ compared to anticoagulation clinics $(73 \%)$

No difference in major complication rates between telemedicine use in peripheral units and anticoagulation clinics

Feasibility:

Progressive increase in telemedicine clinic productivity over the course of the study

Accessibility:

Rural outreach increased from $19 \%$ to $29 \%$ of total clinic activity over the course of the study

Satisfaction:

No significant difference in patient satisfaction between telemedicine and standard care groups

Patients in the standard care group were more likely to offer positive open-ended comments than the telemedicine group

Reasons for negative comments in the telemedicine group included confidentiality, technology, and access

Clinical outcomes:

No significant difference in clinic encounter time between telemedicine and standard care groups

Clinical outcomes:

High adherence rate for follow-up visits $(87.5 \%)$

Improved symptom management

Satisfaction:

High satisfaction with e-clinic visits

\section{Study Outcomes in Video Telemedicine Interventions \\ Pediatric Video Interventions}

Adler et al reported greater than $80 \%$ case review round attendee satisfaction with telemedicine case consultations and patient care education for children with cancer and blood disorders [75]. Improved satisfaction and communication among health care providers and caregivers with the use of videoconferencing at home for children with hemophilia were also noted by Jacobson et al [78].

\section{Adult Video Interventions}

Many telehealth nursing sessions have shown positive outcomes for patients with malignant hematological conditions [53]. Likewise, patients with hematological malignancies felt that they could talk easily and openly with the nurse who led telemedicine follow-up visits in between visits with the oncologist [64]. Telemedicine reportedly improved productivity [72] and increased mean cognitive skills quotient scores for patients [73], but caused no significant decrease in clinic encounter times [71]. Wright et al reported high follow-up adherence rates, good condition management, and high 
satisfaction for e-clinic visits in allogenic blood and stem cell transplant patients [74]. Clarke et al found that teleconsults in British Columbia were most often used with medical oncologists [58].

\section{Study Outcomes in Telephone Telemedicine Interventions}

\section{Pediatric Telephone Interventions}

Agarwal et al found comparable health outcomes at a lower cost through the implementation of an online information technology database platform for patients receiving bone marrow transplants [76]. Stulac et al found that 13 of 24 Rwandan patients with pediatric cancer were in remission at the end of data collection following collaboration with United States-based physicians and nurses through telemedicine interventions [81].

\section{Adult Telephone Interventions}

Telephone therapy was utilized by Applebaum et al, which resulted in decreased depressive symptoms in hematopoietic stem cell transplant survivors with concurrent posttraumatic stress disorder [52]. For patients taking anticoagulants, Blissit et al noticed that telephone interventions led to significantly lower rates of bleeding in patients compared to face-to-face visits [55]. However, Philip et al did not see a significant difference in time within the therapeutic range, hospitalization, or bleeding with a telephone-based anticoagulation service [65]. Reid et al and Flannery et al utilized phone services to address patient questions and symptoms $[60,67]$. Reid et al noted that $36.8 \%$ of calls led to a medical assessment [67]; however, Flannery et al reported no notable improvements with the telephone triage [60]. Biweekly calls for monitoring vitals, side-effects [59], and telephone counseling [61] have all shown benefits for patients with malignant hematological conditions.

\section{Study Outcomes in Web-Based Telemedicine Interventions}

\section{Pediatric Web-Based Interventions}

Cox et al found that patients, families, and caregivers had high rates of intervention participation and reported a positive experience with the introduction of a remote automated working memory intervention for childhood cancer survivors [77]. Telemedicine interventions also received high ratings from primary care providers and resulted in hematology consult deferral, according to Johnston et al [79]. Similarly, Pedrosa et al reported positive outcomes, with decreased rates of mortality, early death, and acute lymphoblastic leukemia relapse following implementation of a telemedicine program that allowed for knowledge sharing between high- and low-income countries [80].

\section{Adult Web-Based Interventions}

Based on a survey by Checchini et al, more than half of patients with nonmalignant hematological disorders preferred e-consults over face-to-face visits, and satisfaction was noted in all providers [57]. Breen et al found increased feelings of empowerment, health awareness, and medication adherence with the use of a telemedicine-based smartphone app that directly transmitted health data to the hospital for patients with blood cancers [42]. Najafi et al also noted that the majority of hospitalists and consultants found e-consult to be a feasible administration of subspecialty health services at a remotely-located hospital [63]. Primary care providers were satisfied with e-consult technology in a survey by Skeith et al, especially since $47.5 \%$ of in-person visits were avoided through the use of this telemedicine intervention [68]. Kirsh et al also reported a decreased number of face-to-face visits in patients using e-consult telemedicine interventions [62]. Additionally. Burwick et al saw that e-consults for hematology cases in patients with monoclonal gammopathy of undetermined significance led to a decrease in the time it took to complete the consultation [56]. In a study by Syrjala et al that included cancer patients treated with hematopoietic stem cell transplantation, over half of participating patients used an online platform and reported the need for staff contact one or more times per day, usually for minor assistance [69]. Barcellona et al reported an increased number of blood checks, fewer missed international normalized ratio checks in the home monitoring group, and a significant increase in the time within the therapeutic range for patients treated with vitamin $\mathrm{K}$ antagonists when using a smartphone app to monitor treatment [54]. Vitamin K antagonist users also had lower rates of bleeding, hospitalization, and all-cause mortality with the use of an online electronic file [66]. Electronic medical record implementation for remote anticoagulation management, however, showed no significant difference in the time within the therapeutic range or major complication rates in nursing homes [70]. Agrawal et al found that a call center allowed for increased recruitment of blood donors [51].

\section{Discussion}

\section{Principal Findings}

Overall, the vast majority of telemedicine interventions studied in this systematic review were shown to have a positive or neutral impact on patients, families, and health care providers. Telemedicine was found to be particularly useful for rural communities, patients in countries with less access to care, and patients with chronic conditions that require routine monitoring and communication with doctors [53,64,71-73,75,78,80,81]. Most studies showed improved or similar outcomes in groups that utilized telemedicine compared to those that did not. However, more research would be beneficial to determine telemedicine's role in hematology and future implications for its use in the clinical setting. This evidence could also potentially increase patient satisfaction and patient-reported health outcomes.

\section{Telemedicine Interventions in Hematology: Expansion of Team-Based Medicine}

In the realm of hematology, many new telemedicine interventions have emerged in recent years to expand the reach of specialty health care and improve patient outcomes [83,84]. Kulkarni et al reported that school-based telemedicine has provided access to multidisciplinary teams for the treatment of hemophilia and related bleeding disorders [84]. In patients who have undergone hematopoietic stem cell transplantation, therapy 
compliance and surveillance are seen to be good areas to implement telemedicine [83].

\section{Telemedicine Interventions in Hematology: Areas of Further Study}

Future use of telemedicine in hematology and other subspecialties should focus on increasing the usage of videoconferencing with physicians from patient homes and making telemedicine more accessible to a wider range of patient populations [85]. This is especially the case for rural areas or regions where specialty health care and access to medical resources are limited [86]. The current COVID-19 pandemic has shown the value of maintaining and developing different ways of patient care, such as through the increased implementation of telemedicine in clinics and hospitals [87]. Various specialties should investigate ways in which they can best implement telemedicine interventions into their own field to improve access and care [86]. The next steps should include the wide use of triage systems that allow patients to be screened for telemedicine use eligibility [87].

\section{Telemedicine Interventions in Other Medical Specialties}

In addition to the use of telemedicine in hematological conditions, it is widely used in various other medical specialties [88-93]. Meta-analyses on telemental health care have reported that applying telemedicine to psychotherapy not only improves patient satisfaction and access to care by circumventing the stigma of seeking in-person mental health care, but also offers a more financially prudent and flexible method of treatment [88]. Telemedicine has also been reported to contribute to shorter lengths of hospital stay and lower hospital mortality [90]. Multiple studies have shown it to be a cost-effective and accessible provision of mental health services [88]. Positive user outcomes with telehealth implementation in emergency rooms have indicated another area of potential use [91]. Similarly, telemedicine has been seen to help in the secondary prevention of stroke and in transient ischemia attack patients, but more research is needed to bolster evidence [93]. Cancer survivors generally had positive attitudes toward self-management and eHealth, but there was variation in the care needs depending on the type of cancer [92]. Telemonitoring is rarely used in prenatal care, but has potential in monitoring pregnant women who are at risk for preterm delivery [89]. These studies emphasize the positive experiences patients and providers have had with telemedicine in various fields of medicine, which further suggests that telemedicine is feasible, accessible, and beneficial. Many of the telemedicine interventions used in these other medical specialties can also be applied to the setting of hematology.

\section{Barriers to Telemedicine}

Though studies indicate high reports of satisfaction from patients and providers in malignant and nonmalignant hematology $[57,68,79,94]$, the incorporation of telemedicine in modern medicine still faces limitations and organizational barriers, including legal liability, cost and reimbursement, and confidentiality concerns [15]. Patient barriers, such as age, computer literacy, and education, also make telemedicine difficult to implement universally [15]. Additionally, technological barriers, including inadequate bandwidth, technically challenged staff, and licensing issues, can limit the scope of telemedicine [15]. There are also concerns regarding the availability of resources in languages other than English [82], lack of notable improvements with telephone triaging [60], efficiency of face-to-face visits [71], and quality of care delivered via e-consult [63]. Funding for both staff and equipment, privacy concerns, internet connection, and home recording all need to be addressed when considering the feasibility of telemedicine [15,95-97]. Since the cost-effectiveness of telemedicine varies across delivery settings [9], more research needs to be done to substantiate evidence of improvement in patient outcomes with the use of telemedicine. Furthermore, the ethics of telemedicine and digital health use in the clinical setting must be discussed. The ethical and legal concerns regarding the use of telemedicine have delayed the rapid widespread implementation of these technologies in multiple aspects of health care [98-100]. Specifically, data confidentiality, patient privacy, physician-patient relationships, and informed consent are all areas that need to be addressed [99,101-103]. Further work must be done to ensure that data management is conducted properly and the social implications or risks are communicated clearly to patients and physicians using telemedicine in practice [99,101-103]. However, despite its barriers, the ability of telemedicine to mediate many of the shortcomings associated with traditional face-to-face consultations still makes telemedicine particularly attractive to many fields, especially hematology.

\section{Strengths}

Our systematic review has a number of strengths. First, we conducted our review following the recommendations for rigorous systematic reviews [49]. Second, we used a highly sensitive and specific search strategy guided by a librarian information specialist. There was no restriction on the country of study in order to minimize publication bias by identifying as many relevant studies as possible. Additional resources were searched, including published systematic reviews, clinical trial registries, and multiple electronic databases. Third, we employed no date restrictions on our search; no included articles were published prior to 1998 . Therefore, the possibility that we missed earlier studies is very small. Finally, two authors completed the review process independently at all stages.

\section{Limitations}

Some potential methodological limitations of our systematic review must be addressed. First, some relevant articles could have been missed in our literature search, despite our comprehensive search strategy in different databases. Second, articles included in the review were strictly peer-reviewed, which could cause publication bias from reporting only positive study results [104]. Third, the ranges of sample size and age, differences between malignant and nonmalignant conditions, and types of telemedicine interventions varied greatly among the studies. Lastly, the number of studies eligible for the review was relatively low; however, this may be a result of the specificity of hematological conditions and the limited number of available publications about the topic. 


\section{Conclusions}

Telemedicine is a recognized and cost-effective way of managing hematological conditions. Evidence from this systematic review suggests that telemedicine provides similar or improved health care compared to traditional face-to-face care. Videoconferencing, telephone-based services, and web-based services were also well received by patients, families, and health care providers in both pediatric and adult settings. However, due to the limited total number of articles and low quality of evidence of the included studies, further research must be done to determine the efficacy and plausibility of widespread implementation of telemedicine in hematology.

\section{Acknowledgments}

This project was supported by a grant (K23HL150232, PI: SMB) from the National Heart, Lung, and Blood Institute (NHLBI) of the National Institutes of Health (NIH). The content is solely the responsibility of the authors and does not necessarily represent the views of the NIH. We thank Mary Therese Forsyth, BS (UCD School of Medicine, University College Dublin, Dublin, Ireland) and Bryn Dougherty, BS (Ohio State University College of Medicine, Columbus, OH) for their help in different parts of the project.

\section{Conflicts of Interest}

None declared.

\section{Multimedia Appendix 1}

Literature search strategies across different databases.

[DOCX File, 20 KB-Multimedia Appendix 1]

\section{Multimedia Appendix 2}

Additional results of the included studies in pediatric populations.

[DOCX File , 18 KB-Multimedia Appendix 2]

\section{Multimedia Appendix 3}

Additional results of the included studies in adult populations.

[DOCX File, 25 KB-Multimedia Appendix 3]

\section{References}

1. Culmer N, Smith T, Stager C, Meyer H, Quick S, Grimm K. Evaluation of the triple aim of medicine in prehospital telemedicine: A systematic literature review. J Telemed Telecare 2020 Dec;26(10):571-580. [doi:

10.1177/1357633X19853461] [Medline: 31238783]

2. Tomines A. Pediatric Telehealth: Approaches by Specialty and Implications for General Pediatric Care. Adv Pediatr 2019 Aug;66:55-85. [doi: 10.1016/j.yapd.2019.04.005] [Medline: 31230700]

3. Sood S, Mbarika V, Jugoo S, Dookhy R, Doarn CR, Prakash N, et al. What is telemedicine? A collection of 104 peer-reviewed perspectives and theoretical underpinnings. Telemed J E Health 2007 Oct;13(5):573-590. [doi: 10.1089/tmj.2006.0073]

[Medline: 17999619]

4. Alonso W, Crouch E, Thorell N. National Rural Health Association Policy Paper: Telehealth in Rural America. National Rural Health Association. URL: https://www.ruralhealthweb.org/NRHA/media/Emerge_NRHA/Advocacy/ Policy\%20documents/2019-NRHA-Policy-Document-Telehealth-In-Rural-America.pdf [accessed 2021-02-01]

5. Bashshur RL. On the definition and evaluation of telemedicine. Telemed J 1995;1(1):19-30. [doi: 10.1089/tmj.1.1995.1.19] [Medline: 10165319]

6. Telemedicine: Opportunities and Developments in Member States. World Health Organization. 2010. URL: https://www. who.int/goe/publications/goe telemedicine 2010.pdf [accessed 2021-02-13]

7. AMA Telemedicine Policy. American Medical Association. 2017. URL: https://www.ama-assn.org/sites/ama-assn.org/ files/corp/media-browser/public/arc-public/telemed-policy.pdf [accessed 2021-01-31]

8. Field MJ. Telemedicine: a guide to assessing telecommunications in healthcare. J Digit Imaging 1997 Aug;10(3 Suppl 1):28 [FREE Full text] [doi: 10.1007/BF03168648] [Medline: 9268830]

9. Wilson LS, Maeder AJ. Recent Directions in Telemedicine: Review of Trends in Research and Practice. Healthc Inform Res 2015 Oct;21(4):213-222 [FREE Full text] [doi: 10.4258/hir.2015.21.4.213] [Medline: 26618026]

10. Badawy SM, Thompson AA, Liem RI. Technology Access and Smartphone App Preferences for Medication Adherence in Adolescents and Young Adults With Sickle Cell Disease. Pediatr Blood Cancer 2016 May;63(5):848-852. [doi: 10.1002/pbc.25905] [Medline: 26844685] 
11. Heneghan MB, Hussain T, Barrera L, Cai SW, Haugen M, Morgan E, et al. Access to Technology and Preferences for an mHealth Intervention to Promote Medication Adherence in Pediatric Acute Lymphoblastic Leukemia: Approach Leveraging Behavior Change Techniques. J Med Internet Res 2021 Feb 18;23(2):e24893 [FREE Full text] [doi: 10.2196/24893] [Medline: 33599621]

12. Shah N, Jonassaint J, De Castro L. Patients welcome the Sickle Cell Disease Mobile Application to Record Symptoms via Technology (SMART). Hemoglobin 2014;38(2):99-103. [doi: 10.3109/03630269.2014.880716] [Medline: 24512633]

13. Perrin A. 10 facts about smartphones as the iPhone turns 10. Pew Research Center. 2017. URL: https://www.pewresearch.org/ fact-tank/2017/06/28/10-facts-about-smartphones/ [accessed 2021-02-14]

14. Perrin A. Mobile Fact Sheet. Pew Research Center. URL: https://www.pewresearch.org/internet/fact-sheet/mobile/ [accessed 2021-02-15]

15. Scott Kruse C, Karem P, Shifflett K, Vegi L, Ravi K, Brooks M. Evaluating barriers to adopting telemedicine worldwide: A systematic review. J Telemed Telecare 2018 Jan;24(1):4-12 [FREE Full text] [doi: 10.1177/1357633X16674087] [Medline: 29320966]

16. Burke BL, Hall RW, Section on telehealth care. Telemedicine: Pediatric Applications. Pediatrics 2015 Jul;136(1):e293-e308 [FREE Full text] [doi: 10.1542/peds.2015-1517] [Medline: 26122813]

17. Badawy SM, Barrera L, Sinno MG, Kaviany S, O'Dwyer LC, Kuhns LM. Text Messaging and Mobile Phone Apps as Interventions to Improve Adherence in Adolescents With Chronic Health Conditions: A Systematic Review. JMIR Mhealth Uhealth 2017 May 15;5(5):e66 [FRE Full text] [doi: 10.2196/mhealth.7798] [Medline: 28506955]

18. Badawy SM, Cronin RM, Hankins J, Crosby L, DeBaun M, Thompson AA, et al. Patient-Centered eHealth Interventions for Children, Adolescents, and Adults With Sickle Cell Disease: Systematic Review. J Med Internet Res 2018 Jul 19;20(7):e10940 [FREE Full text] [doi: 10.2196/10940] [Medline: 30026178]

19. Badawy SM, Kuhns LM. Texting and Mobile Phone App Interventions for Improving Adherence to Preventive Behavior in Adolescents: A Systematic Review. JMIR Mhealth Uhealth 2017 Apr 19;5(4):e50 [FREE Full text] [doi: 10.2196/mhealth.6837] [Medline: 28428157]

20. Badawy SM, Morrone K, Thompson A, Palermo TM. Computer and mobile technology interventions to promote medication adherence and disease management in people with thalassemia. Cochrane Database Syst Rev 2019 Jun 28;6:CD012900 [FREE Full text] [doi: 10.1002/14651858.CD012900.pub2] [Medline: 31250923]

21. Badawy SM, Radovic A. Digital Approaches to Remote Pediatric Health Care Delivery During the COVID-19 Pandemic: Existing Evidence and a Call for Further Research. JMIR Pediatr Parent 2020 Jun 25;3(1):e20049 [FREE Full text] [doi: 10.2196/20049] [Medline: $\underline{32540841]}$

22. Radovic A, Badawy SM. Technology Use for Adolescent Health and Wellness. Pediatrics 2020 May;145(Suppl 2):S186-S194 [FREE Full text] [doi: 10.1542/peds.2019-2056G] [Medline: $\underline{\text { 32358210] }}$

23. Ramsey WA, Heidelberg RE, Gilbert AM, Heneghan MB, Badawy SM, Alberts NM. eHealth and mHealth interventions in pediatric cancer: A systematic review of interventions across the cancer continuum. Psychooncology 2020 Jan;29(1):17-37. [doi: 10.1002/pon.5280] [Medline: 31692183]

24. Alberts NM, Badawy SM, Hodges J, Estepp JH, Nwosu C, Khan H, et al. Development of the InCharge Health Mobile App to Improve Adherence to Hydroxyurea in Patients With Sickle Cell Disease: User-Centered Design Approach. JMIR Mhealth Uhealth 2020 May 08;8(5):e14884 [FREE Full text] [doi: 10.2196/14884] [Medline: $\underline{32383683}$ ]

25. Badawy SM, Shah R, Beg U, Heneghan MB. Habit Strength, Medication Adherence, and Habit-Based Mobile Health Interventions Across Chronic Medical Conditions: Systematic Review. J Med Internet Res 2020 Apr 28;22(4):e17883 [FREE Full text] [doi: 10.2196/17883] [Medline: $\underline{\text { 32343250] }}$

26. Shah AC, Badawy SM. Telemedicine in Pediatrics: Systematic Review of Randomized Controlled Trials. JMIR Pediatr Parent 2021 Feb 24;4(1):e22696 [FREE Full text] [doi: 10.2196/22696] [Medline: 33556030]

27. de Jongh T, Gurol-Urganci I, Vodopivec-Jamsek V, Car J, Atun R. Mobile phone messaging for facilitating self-management of long-term illnesses. Cochrane Database Syst Rev 2012 Dec 12;12:CD007459 [FREE Full text] [doi: 10.1002/14651858.CD007459.pub2] [Medline: 23235644]

28. Gurol-Urganci I, de Jongh T, Vodopivec-Jamsek V, Atun R, Car J. Mobile phone messaging reminders for attendance at healthcare appointments. Cochrane Database Syst Rev 2013 Dec 05;12(12):CD007458 [FREE Full text] [doi: 10.1002/14651858.CD007458.pub3] [Medline: 24310741]

29. Lin $\mathrm{H}, \mathrm{Wu} \mathrm{X}$. Intervention strategies for improving patient adherence to follow-up in the era of mobile information technology: a systematic review and meta-analysis. PLoS One 2014;9(8):e104266 [FREE Full text] [doi: 10.1371/journal.pone.0104266] [Medline: 25100267]

30. Liu Q, Abba K, Alejandria MM, Sinclair D, Balanag VM, Lansang MAD. Reminder systems to improve patient adherence to tuberculosis clinic appointments for diagnosis and treatment. Cochrane Database Syst Rev 2014 Nov 18(11):CD006594 [FREE Full text] [doi: 10.1002/14651858.CD006594.pub3] [Medline: 25403701]

31. Majeed-Ariss R, Baildam E, Campbell M, Chieng A, Fallon D, Hall A, et al. Apps and Adolescents: A Systematic Review of Adolescents' Use of Mobile Phone and Tablet Apps That Support Personal Management of Their Chronic or Long-Term Physical Conditions. J Med Internet Res 2015 Dec 23;17(12):e287 [FREE Full text] [doi: 10.2196/jmir.5043] [Medline: $\underline{26701961]}$ 
32. Payne HE, Lister C, West JH, Bernhardt JM. Behavioral functionality of mobile apps in health interventions: a systematic review of the literature. JMIR Mhealth Uhealth 2015 Feb 26;3(1):e20 [FREE Full text] [doi: 10.2196/mhealth.3335] [Medline: 25803705]

33. Badawy SM. Technology and Long-Term Health-Related Quality-of-Life Outcomes in Children with Nonmalignant Disorders after Reduced-Intensity Conditioning and Stem Cell Transplantation. Biol Blood Marrow Transplant 2016 Sep;22(9):1733 [FREE Full text] [doi: 10.1016/j.bbmt.2016.06.015] [Medline: 27328128]

34. Pfaeffli Dale L, Dobson R, Whittaker R, Maddison R. The effectiveness of mobile-health behaviour change interventions for cardiovascular disease self-management: A systematic review. Eur J Prev Cardiol 2016 May;23(8):801-817. [doi: 10.1177/2047487315613462] [Medline: 26490093]

35. Thakkar J, Kurup R, Laba T, Santo K, Thiagalingam A, Rodgers A, et al. Mobile Telephone Text Messaging for Medication Adherence in Chronic Disease: A Meta-analysis. JAMA Intern Med 2016 Mar;176(3):340-349. [doi:

10.1001/jamainternmed.2015.7667] [Medline: 26831740]

36. Badawy SM, Thompson AA, Kuhns LM. Medication Adherence and Technology-Based Interventions for Adolescents With Chronic Health Conditions: A Few Key Considerations. JMIR Mhealth Uhealth 2017 Dec 22;5(12):e202 [FREE Full text] [doi: 10.2196/mhealth.8310] [Medline: 29273573]

37. Bonoto BC, de Araújo VE, Godói IP, de Lemos LLP, Godman B, Bennie M, et al. Efficacy of Mobile Apps to Support the Care of Patients With Diabetes Mellitus: A Systematic Review and Meta-Analysis of Randomized Controlled Trials. JMIR Mhealth Uhealth 2017 Mar 01;5(3):e4 [FREE Full text] [doi: 10.2196/mhealth.6309] [Medline: 28249834]

38. Perski O, Blandford A, West R, Michie S. Conceptualising engagement with digital behaviour change interventions: a systematic review using principles from critical interpretive synthesis. Transl Behav Med 2017 Jun 13;7(2):254-267 [FREE Full text] [doi: 10.1007/s13142-016-0453-1] [Medline: 27966189]

39. Johnson A, Yang F, Gollarahalli S, Banerjee T, Abrams D, Jonassaint J, et al. Use of Mobile Health Apps and Wearable Technology to Assess Changes and Predict Pain During Treatment of Acute Pain in Sickle Cell Disease: Feasibility Study. JMIR Mhealth Uhealth 2019 Dec 02;7(12):e13671 [FREE Full text] [doi: 10.2196/13671] [Medline: $\underline{31789599]}$

40. Badawy SM, Kuhns LM. Economic Evaluation of Text-Messaging and Smartphone-Based Interventions to Improve Medication Adherence in Adolescents with Chronic Health Conditions: A Systematic Review. JMIR Mhealth Uhealth 2016 Oct 25;4(4):e121 [FREE Full text] [doi: 10.2196/mhealth.6425] [Medline: 27780795]

41. Iribarren SJ, Cato K, Falzon L, Stone PW. What is the economic evidence for mHealth? A systematic review of economic evaluations of mHealth solutions. PLoS One 2017;12(2):e0170581 [FREE Full text] [doi: 10.1371/journal.pone.0170581] [Medline: 28152012]

42. Breen S, Ritchie D, Schofield P, Hsueh Y, Gough K, Santamaria N, et al. The Patient Remote Intervention and Symptom Management System (PRISMS) - a Telehealth- mediated intervention enabling real-time monitoring of chemotherapy side-effects in patients with haematological malignancies: study protocol for a randomised controlled trial. Trials 2015 Oct 19;16:472 [FREE Full text] [doi: 10.1186/s13063-015-0970-0] [Medline: 26481873]

43. Fox P, Darley A, Furlong E, Miaskowski C, Patiraki E, Armes J, et al. The assessment and management of chemotherapy-related toxicities in patients with breast cancer, colorectal cancer, and Hodgkin's and non-Hodgkin's lymphomas: A scoping review. Eur J Oncol Nurs 2017 Feb;26:63-82. [doi: 10.1016/j.ejon.2016.12.008] [Medline: 28069154]

44. Fisher SI, Nandedkar MA, Williams BH, Abbondanzo SL. Telehematopathology in a clinical consultative practice. Hum Pathol 2001 Dec;32(12):1327-1333. [doi: 10.1053/hupa.2001.29654] [Medline: 11774165]

45. Doyle-Lindrud S. Telemedicine in Oncology. Clin J Oncol Nurs 2016 Feb;20(1):27-28. [doi: 10.1188/16.CJON.27-28] [Medline: 26800402]

46. Indini A, Aschele C, Cavanna L, Clerico M, Daniele B, Fiorentini G, et al. Reorganisation of medical oncology departments during the novel coronavirus disease-19 pandemic: a nationwide Italian survey. Eur J Cancer 2020 Jun;132:17-23. [doi: 10.1016/j.ejca.2020.03.024] [Medline: 32311643]

47. Mann DM, Chen J, Chunara R, Testa PA, Nov O. COVID-19 transforms health care through telemedicine: Evidence from the field. J Am Med Inform Assoc 2020 Jul 01;27(7):1132-1135 [FREE Full text] [doi: 10.1093/jamia/ocaa072] [Medline: $\underline{32324855]}$

48. Jacob SA, Carroll AE, Bennett WE. A feasibility study of telemedicine for paediatric sickle cell patients living in a rural medically underserved area. J Telemed Telecare 2019 Nov 06:1357633X19883558. [doi: 10.1177/1357633X19883558] [Medline: 31694482]

49. Moher D, Shamseer L, Clarke M, Ghersi D, Liberati A, Petticrew M, PRISMA-P Group. Preferred reporting items for systematic review and meta-analysis protocols (PRISMA-P) 2015 statement. Syst Rev 2015 Jan 01;4:1 [FREE Full text] [doi: 10.1186/2046-4053-4-1] [Medline: 25554246]

50. Atkins D, Best D, Briss PA, Eccles M, Falck-Ytter Y, Flottorp S, GRADE Working Group. Grading quality of evidence and strength of recommendations. BMJ 2004 Jun 19;328(7454):1490 [FREE Full text] [doi: 10.1136/bmj.328.7454.1490] [Medline: 15205295]

51. Agrawal A, Tiwari A. Tele-recruitment for Donor Retention. Indian J Hematol Blood Transfus 2014 Mar;30(1):22-25 [FREE Full text] [doi: 10.1007/s12288-012-0197-0] [Medline: 24554816] 
52. Applebaum AJ, DuHamel KN, Winkel G, Rini C, Greene PB, Mosher CE, et al. Therapeutic alliance in telephone-administered cognitive-behavioral therapy for hematopoietic stem cell transplant survivors. J Consult Clin Psychol 2012 Oct;80(5):811-816 [FREE Full text] [doi: 10.1037/a0027956] [Medline: 22468908]

53. Bakitas MA, Tosteson TD, Li Z, Lyons KD, Hull JG, Li Z, et al. Early Versus Delayed Initiation of Concurrent Palliative Oncology Care: Patient Outcomes in the ENABLE III Randomized Controlled Trial. J Clin Oncol 2015 May 01;33(13):1438-1445 [FREE Full text] [doi: 10.1200/JCO.2014.58.6362] [Medline: 25800768]

54. Barcellona D, Fenu L, Cornacchini S, Marongiu F. Telemedicine can improve the quality of oral anticoagulation using portable devices and self-testing at home. J Telemed Telecare 2013 Sep;19(6):298-301. [doi: 10.1177/1357633X13501764] [Medline: 24163291]

55. Blissit KT, Mullenix ML, Brittain KG. Evaluation of Time in Therapeutic Range on Warfarin Therapy Between Face-to-Face and Telephone Follow-Up in a VA Medical Center. Journal of Pharmacy Technology 2014 Oct 01;31(2):78-83. [doi: $10.1177 / 8755122514552497]$

56. Burwick N, Stein J, Garcia DA, Broudy VC, Richard RE. Monoclonal gammopathies: Electronic subspecialty consultation. Eur J Haematol 2018 Apr;100(4):351-355. [doi: 10.1111/ejh.13019] [Medline: 29281132]

57. Cecchini M, Rose MG, Wong EY, Neparidze N. The implementation of electronic hematology consults at a VA hospital. Blood 2016 Mar 24;127(12):1610-1611 [FREE Full text] [doi: 10.1182/blood-2015-09-672113] [Medline: 26809506]

58. Clarke M, Barnett J. Teleoncology uptake in British Columbia. Stud Health Technol Inform 2011;164:399-404. [Medline: 21335743]

59. Compaci G, Ysebaert L, Obéric L, Derumeaux H, Laurent G. Effectiveness of telephone support during chemotherapy in patients with diffuse large B cell lymphoma: the Ambulatory Medical Assistance (AMA) experience. Int J Nurs Stud 2011 Aug;48(8):926-932. [doi: 10.1016/j.ijnurstu.2011.01.008] [Medline: 21349519]

60. Flannery M, Phillips SM, Lyons CA. Examining telephone calls in ambulatory oncology. J Oncol Pract 2009 Mar;5(2):57-60 [FREE Full text] [doi: 10.1200/JOP.0922002] [Medline: 20856719]

61. Hung Y, Bauer JD, Horsely P, Coll J, Bashford J, Isenring EA. Telephone-delivered nutrition and exercise counselling after auto-SCT: a pilot, randomised controlled trial. Bone Marrow Transplant 2014 Jun;49(6):786-792. [doi: 10.1038/bmt.2014.52] [Medline: 24710562]

62. Kirsh S, Carey E, Aron DC, Cardenas O, Graham G, Jain R, et al. Impact of a national specialty e-consultation implementation project on access. Am J Manag Care 2015 Dec 01;21(12):e648-e654 [FREE Full text] [Medline: 26760427]

63. Najafi N, Harrison JD, Duong J, Greenberg A, Cheng HQ. It All Just Clicks: Development of an Inpatient E-Consult Program. J Hosp Med 2017 May;12(5):332-334. [doi: 10.12788/jhm.2740] [Medline: 28459902]

64. Overend A, Khoo K, Delorme M, Krause V, Avanessian A, Saltman D. Evaluation of a nurse-led telephone follow-up clinic for patients with indolent and chronic hematological malignancies: a pilot study. Can Oncol Nurs J 2008;18(2):64-73. [doi: $10.5737 / 1181912 \times 1826468]$ [Medline: 18649698$]$

65. Philip A, Green M, Hoffman T, Gautreaux S, Wallace D, Roux R, et al. Expansion of clinical pharmacy through increased use of outpatient pharmacists for anticoagulation services. Am J Health Syst Pharm 2015 Apr 01;72(7):568-572. [doi: 10.2146/ajhp140404] [Medline: 25788511]

66. Prochaska JH, Göbel S, Keller K, Coldewey M, Ullmann A, Lamparter H, et al. e-Health-based management of patients receiving oral anticoagulation therapy: results from the observational thrombEVAL study. J Thromb Haemost 2017 Jul;15(7):1375-1385 [FREE Full text] [doi: 10.1111/jth.13727] [Medline: 28457013]

67. Reid J, Porter S. Utility, caller, and patient profile of a novel Chemotherapy Telephone Helpline service within a regional cancer centre in Northern Ireland. Cancer Nurs 2011;34(3):E27-E32. [doi: 10.1097/NCC.0b013e318204c53c] [Medline: 21512342]

68. Skeith L, Mohamed M, Karovitch A, Liddy C, Afkham A, Archibald D, et al. The use of eConsults to improve access to specialty care in thrombosis medicine. Thromb Res 2017 Dec;160:105-108. [doi: 10.1016/j.thromres.2017.11.002] [Medline: 29145030]

69. Syrjala KL, Stover AC, Yi JC, Artherholt SB, Romano EM, Schoch G, et al. Development and implementation of an Internet-based survivorship care program for cancer survivors treated with hematopoietic stem cell transplantation. J Cancer Surviv 2011 Sep;5(3):292-304 [FREE Full text] [doi: 10.1007/s11764-011-0182-x] [Medline: 21544671]

70. Testa S, Paoletti O, Zimmermann A, Bassi L, Cancellieri E. Telemedicine For Managing Patients on Oral Anticoagulant Therapy. Telemedicine Techniques and Applications. 2011. URL: https://www.intechopen.com/books/ telemedicine-techniques-and-applications/telemedicine-for-managing-patients-on-oral-anticoagulant-therapy [accessed 2021-07-05]

71. Woods K, Kutlar A, Grigsby RK, Adams L, Stachura ME. Primary-care delivery for sickle cell patients in rural Georgia using telemedicine. Telemed J 1998;4(4):353-361. [doi: 10.1089/tmj.1.1998.4.353] [Medline: 10220476]

72. Woods KF, Johnson JA, Kutlar A, Daitch L, Stachura ME. Sickle cell disease telemedicine network for rural outreach. J Telemed Telecare 2000;6(5):285-290. [doi: 10.1258/1357633001935923] [Medline: 11070590 ]

73. Woods KF, Kutlar A, Johnson JA, Waller JL, Grigsby RK, Stachura ME, et al. Sickle cell telemedicine and standard clinical encounters: a comparison of patient satisfaction. Telemed J 1999;5(4):349-356. [doi: 10.1089/107830299311916] [Medline: $\underline{10908450]}$ 
74. Wright J, Purdy B, McGonigle S. E-Clinic: an innovative approach to complex symptom management for allogeneic blood and stem cell transplant patients. Can Oncol Nurs J 2007;17(4):187-192. [Medline: 18286991]

75. Adler E, Alexis C, Ali Z, Allen U, Bartels U, Bick C, et al. Bridging the Distance in the Caribbean: Telemedicine as a means to build capacity for care in paediatric cancer and blood disorders. Stud Health Technol Inform 2015;209:1-8. [Medline: 25980698]

76. Agarwal RK, Sedai A, Dhimal S, Ankita K, Clemente L, Siddique S, et al. A prospective international cooperative information technology platform built using open-source tools for improving the access to and safety of bone marrow transplantation in low- and middle-income countries. J Am Med Inform Assoc 2014;21(6):1125-1128 [FREE Full text] [doi: 10.1136/amiajnl-2013-002594] [Medline: 24714444]

77. Cox LE, Ashford JM, Clark KN, Martin-Elbahesh K, Hardy KK, Merchant TE, et al. Feasibility and acceptability of a remotely administered computerized intervention to address cognitive late effects among childhood cancer survivors. Neurooncol Pract 2015 Jun;2(2):78-87 [FREE Full text] [doi: 10.1093/nop/npu036] [Medline: 27054041]

78. Jacobson K, Hooke MC. Telehealth Videoconferencing for Children With Hemophilia and Their Families: A Clinical Project. J Pediatr Oncol Nurs 2016 Jul;33(4):282-288. [doi: 10.1177/1043454215607340] [Medline: 26510644]

79. Johnston DL, Murto K, Kurzawa J, Liddy C, Keely E, Lai L. Use of Electronic Consultation System to Improve Access to Care in Pediatric Hematology/Oncology. J Pediatr Hematol Oncol 2017 Oct;39(7):e367-e369. [doi:

10.1097/MPH.0000000000000833] [Medline: 28437292]

80. Pedrosa F, Shaikh F, Rivera G, Ribeiro R, Qaddoumi I. The Impact of Prospective Telemedicine Implementation in the Management of Childhood Acute Lymphoblastic Leukemia in Recife, Brazil. Telemed J E Health 2017 Oct;23(10):863-867 [FREE Full text] [doi: 10.1089/tmj.2016.0273] [Medline: 28422613]

81. Stulac S, Mark Munyaneza RB, Chai J, Bigirimana JB, Nyishime M, Tapela N, et al. Initiating Childhood Cancer Treatment in Rural Rwanda: A Partnership-Based Approach. Pediatr Blood Cancer 2016 May;63(5):813-817. [doi: 10.1002/pbc.25903] [Medline: 26785111]

82. Breen S, Kofoed S, Ritchie D, Dryden T, Maguire R, Kearney N, et al. Remote real-time monitoring for chemotherapy side-effects in patients with blood cancers. Collegian 2017 Dec;24(6):541-549. [doi: 10.1016/j.colegn.2016.10.009]

83. Kharfan-Dabaja MA, Aljurf M. Hematopoietic cell transplantation: Training challenges and potential opportunities through networking and integration of modern technologies to the practice setting. Hematol Oncol Stem Cell Ther 2017 Dec;10(4):184-188 [FREE Full text] [doi: 10.1016/j.hemonc.2017.05.012] [Medline: 28633040]

84. Kulkarni R. Use of telehealth in the delivery of comprehensive care for patients with haemophilia and other inherited bleeding disorders. Haemophilia 2018 Jan;24(1):33-42. [doi: 10.1111/hae.13364] [Medline: 29205699]

85. Klasko SK. Healthcare Transformation: The Future of Telemedicine. Telemed J E Health 2016 May;22(5):337-341. [doi: 10.1089/tmj.2016.29007.skk] [Medline: 27128778]

86. Fortney JC, Pyne JM, Turner EE, Farris KM, Normoyle TM, Avery MD, et al. Telepsychiatry integration of mental health services into rural primary care settings. Int Rev Psychiatry 2015;27(6):525-539. [doi: 10.3109/09540261.2015.1085838] [Medline: 26634618]

87. Bashshur R, Doarn CR, Frenk JM, Kvedar JC, Woolliscroft JO. Telemedicine and the COVID-19 Pandemic, Lessons for the Future. Telemed J E Health 2020 May 08;26(5):571-573. [doi: 10.1089/tmj.2020.29040.rb] [Medline: 32275485]

88. Langarizadeh M, Tabatabaei MS, Tavakol K, Naghipour M, Rostami A, Moghbeli F. Telemental Health Care, an Effective Alternative to Conventional Mental Care: a Systematic Review. Acta Inform Med 2017 Dec;25(4):240-246 [FREE Full text] [doi: 10.5455/aim.2017.25.240-246] [Medline: 29284913]

89. Lanssens D, Vandenberk T, Thijs IM, Grieten L, Gyselaers W. Effectiveness of Telemonitoring in Obstetrics: Scoping Review. J Med Internet Res 2017 Sep 27;19(9):e327 [FREE Full text] [doi: 10.2196/jmir.7266] [Medline: 28954715]

90. Lilly CM, Zubrow MT, Kempner KM, Reynolds HN, Subramanian S, Eriksson EA, Society of Critical Care Medicine Tele-ICU Committee. Critical care telemedicine: evolution and state of the art. Crit Care Med 2014 Nov;42(11):2429-2436. [doi: 10.1097/CCM.0000000000000539] [Medline: 25080052]

91. Ward MM, Jaana M, Natafgi N. Systematic review of telemedicine applications in emergency rooms. Int J Med Inform 2015 Sep;84(9):601-616. [doi: 10.1016/j.ijmedinf.2015.05.009] [Medline: 26072326]

92. Jansen F, van Uden-Kraan CF, van Zwieten V, Witte BI, Verdonck-de Leeuw IM. Cancer survivors' perceived need for supportive care and their attitude towards self-management and eHealth. Support Care Cancer 2015 Jun;23(6):1679-1688. [doi: 10.1007/s00520-014-2514-7] [Medline: 25424520]

93. Kraft P, Hillmann S, Rücker V, Heuschmann PU. Telemedical strategies for the improvement of secondary prevention in patients with cerebrovascular events-A systematic review and meta-analysis. Int J Stroke 2017 Aug;12(6):597-605. [doi: 10.1177/1747493017706188] [Medline: 28440116]

94. Kulkarni R, Mauser-Bunschoten EP, Stedman C, Street A. Medical co-morbidities and practice. Haemophilia 2014 May;20 Suppl 4:130-136. [doi: 10.1111/hae.12403] [Medline: 24762288]

95. Baker RI, Laurenson L, Winter M, Pritchard AM. The impact of information technology on haemophilia care. Haemophilia 2004 Oct;10 Suppl 4:41-46. [doi: 10.1111/j.1365-2516.2004.00995.x] [Medline: 15479371]

96. Binder AF, Gabrilove J. A path forward: Global health, telemedicine, and hematology. Am J Hematol 2016 Aug;91(8):E333-E334 [FREE Full text] [doi: 10.1002/ajh.24418] [Medline: 27178529] 
97. de la Torre-Díez I, López-Coronado M, Vaca C, Aguado JS, de Castro C. Cost-utility and cost-effectiveness studies of telemedicine, electronic, and mobile health systems in the literature: a systematic review. Telemed J E Health 2015 Feb;21(2):81-85 [FREE Full text] [doi: 10.1089/tmj.2014.0053] [Medline: 25474190]

98. Chaet D, Clearfield R, Sabin JE, Skimming K, Council on Ethical Judicial Affairs American Medical Association. Ethical practice in Telehealth and Telemedicine. J Gen Intern Med 2017 Oct;32(10):1136-1140 [FREE Full text] [doi: 10.1007/s11606-017-4082-2] [Medline: 28653233]

99. Langarizadeh M, Moghbeli F, Aliabadi A. Application of Ethics for Providing Telemedicine Services and Information Technology. Med Arch 2017 Oct;71(5):351-355 [FREE Full text] [doi: 10.5455/medarh.2017.71.351-355] [Medline: 29284905]

100. Nittari G, Khuman R, Baldoni S, Pallotta G, Battineni G, Sirignano A, et al. Telemedicine Practice: Review of the Current Ethical and Legal Challenges. Telemed J E Health 2020 Dec;26(12):1427-1437 [FREE Full text] [doi: 10.1089/tmj.2019.0158] [Medline: $\underline{\text { 32049608] }}$

101. Nebeker C, Harlow J, Espinoza Giacinto R, Orozco-Linares R, Bloss CS, Weibel N. Ethical and regulatory challenges of research using pervasive sensing and other emerging technologies: IRB perspectives. AJOB Empir Bioeth 2017;8(4):266-276. [doi: 10.1080/23294515.2017.1403980] [Medline: 29125425]

102. Nebeker C, Murray K, Holub C, Haughton J, Arredondo EM. Acceptance of Mobile Health in Communities Underrepresented in Biomedical Research: Barriers and Ethical Considerations for Scientists. JMIR Mhealth Uhealth 2017 Jun 28;5(6):e87 [FREE Full text] [doi: 10.2196/mhealth.6494] [Medline: 28659258]

103. Torous J, Nebeker C. Navigating Ethics in the Digital Age: Introducing Connected and Open Research Ethics (CORE), a Tool for Researchers and Institutional Review Boards. J Med Internet Res 2017 Feb 08;19(2):e38 [FREE Full text] [doi: 10.2196/jmir.6793] [Medline: 28179216]

104. Dubben H, Beck-Bornholdt H. Systematic review of publication bias in studies on publication bias. BMJ 2005 Aug 20;331(7514):433-434 [FREE Full text] [doi: 10.1136/bmj.38478.497164.F7] [Medline: 15937056]

\section{Abbreviations \\ GRADE: Grades of Recommendation, Assessment, Development, and Evaluation PRISMA: Preferred Reporting Items for Systematic Reviews and Meta-Analyses \\ RCT: randomized controlled trial}

Edited by G Eysenbach; submitted 14.04.21; peer-reviewed by C Jonassaint, S Norell; comments to author 07.05.21; revised version
received $21.05 .21 ;$ accepted $31.05 .21 ;$ published 08.07 .21
Please cite as:
Shah AC, O'Dwyer LC, Badawy SM
Telemedicine in Malignant and Nonmalignant Hematology: Systematic Review of Pediatric and Adult Studies
JMIR Mhealth Uhealth 2021;9(7):e29619
URL: $\underline{\text { https://mhealth.jmir.org/2021/7/e29619 }}$
doi: $\underline{10.2196 / 29619}$
PMID: $\underline{34255706}$

(C)Aashaka C Shah, Linda C O'Dwyer, Sherif M Badawy. Originally published in JMIR mHealth and uHealth (https://mhealth.jmir.org), 08.07.2021. This is an open-access article distributed under the terms of the Creative Commons Attribution License (https://creativecommons.org/licenses/by/4.0/), which permits unrestricted use, distribution, and reproduction in any medium, provided the original work, first published in JMIR mHealth and uHealth, is properly cited. The complete bibliographic information, a link to the original publication on https://mhealth.jmir.org/, as well as this copyright and license information must be included. 